\title{
Immuno- and glyco-histochemistry as a tool to evaluate the oregano supplemented feed effects in pig gut
}

\author{
Cecilia Dall'Aglio, ${ }^{1}$ Francesca Mercati, ${ }^{1}$ Valerio Faeti, ${ }^{2}$ Gabriele Acuti, ${ }^{1}$ Massimo Trabalza-Marinucci, ${ }^{1}$ \\ Elena De Felice, ${ }^{3}$ Federico Maria Tardella, ${ }^{3}$ Maria Pia Franciosini, ${ }^{1}$ Patrizia Casagrande Proietti, ${ }^{1}$ Daniele Catorci, ${ }^{4,5}$ \\ Paolo Stacchini, ${ }^{6}$ Augusto Pastorelli, ${ }^{6}$ Paola Scocco ${ }^{3}$ \\ ${ }^{1}$ Department of Veterinary Medicine, University of Perugia \\ ${ }^{2}$ Council for Agricultural Research and Economics, Research Centre for Animal Production and Aquaculture, \\ San Cesario sul Panaro \\ ${ }^{3}$ School of Biosciences and Veterinary Medicine, University of Camerino \\ ${ }^{4}$ Bioorganic Chemistry Laboratory, Department of Physics, University of Trento, Povo \\ ${ }^{5}$ Department of Cellular, Computational and Integrative Biology (CIBIO), University of Trento, Povo \\ ${ }^{6}$ Department of Food Safety, Nutrition and Veterinary Public Health, Istituto Superiore di Sanità, Rome, Italy
}

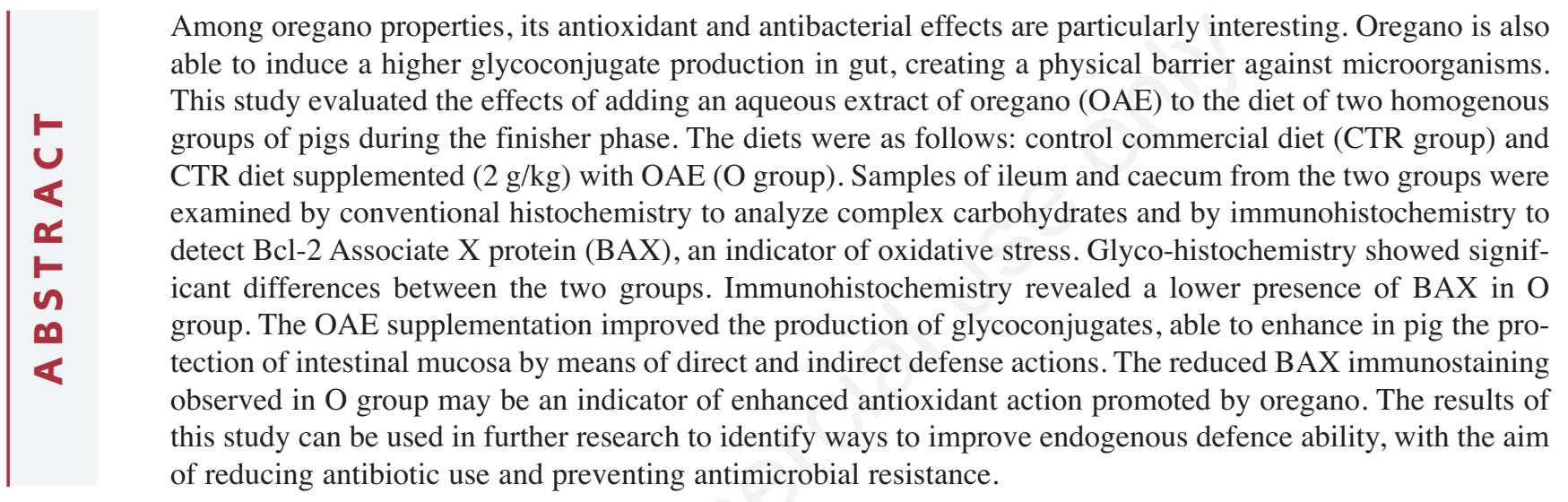

Key words: Swine; intestine; Origanum vulgare L.; glycohistochemistry; immunohistochemistry; BAX.

Correspondence: Francesca Mercati, Department of Veterinary Medicine, University of Perugia, Via San Costanzo 4, 06126, Perugia, Italy.

Tel. +39.075.5857636 - Fax: +39.075.5857631. E-mail: francesca.mercati@unipg.it

Contributions: PSc, CDA, MTM, MPF, conceptualization; PSc, FM, CDA, methodology and validation; DC, PSt, AP, chemical analysis; FMT, formal analysis; EDF, VF, GA, investigation; EDF, PCP, writing, review and editing; PSc, CDA, FM, supervision.

All authors revised and approved the manuscript.

Conflict of interest: The authors declare that they have no competing interests, and all authors confirm accuracy.

Ethical Approval: This research was approved by the Ethics Committee of the University of Camerino, Italy (Protocol E81AC.10/A). 


\section{Introduction}

A number of studies in recent years have focused on the use of natural compounds from herbs and spices as an alternative to synthetic antibiotics, in order to avoid the growing problem of antibiotic resistance. ${ }^{1}$ Among the officinal plants, Origanum vulgare L., belonging to Lamiaceae family, has been shown to possess antioxidant, anti-bacterial, anti-fungal, anti-inflammatory, anti-tumour, anti-parasitic, anti-viral, anti-hyperglycemic, anti-cholinesterase, diaphoretic, carminative, antispasmodic and analgesic activities, which are mainly attributed to its components carvacrol, limonene, gamma-caryophyllene, rhocymenene, camphor, linalool, alphapinene and thymol., ${ }^{2,3}$ Of particular interest among the oregano properties are its antioxidant and antibacterial ones.

The oxidative reactions that can take place in cells may produce reactive oxygen species (ROS) and free radicals that, if not properly disposed of, can lead to the pathological condition of oxidative stress. Currently, the oxidative stress is defined as a situation in which steady-state ROS concentration is transiently or chronically enhanced, disturbing cellular metabolism and its regulation and, in turn, damaging cellular constituents. ${ }^{4,5}$ Oxidative stress may be induced either by externally added oxidants and compounds or stimulating ROS production and weakening antioxidant defence. ${ }^{6}$ The antioxidants protect the cells, and thus protect the whole organism, because they give the possibility to living organisms to adjust their defense systems to enhanced ROS levels. The antioxidant properties of oregano have been attributed to the phenolic and flavonoid compounds it contains. ${ }^{7}$ Just as the antioxidant properties of oregano have been attributed in part to its content in phenolic compounds, so its antibacterial action against Gram-negative and Gram-positive bacteria has been related to these components, in particular, their hydroxyl groups, which alter bacterial membrane integrity. ${ }^{8}$ The use of oregano essential oil (EO) has been examined in animal nutrition studies and the effects of EO compounds as antimicrobials against gut pathogens are documented. ${ }^{9-12}$ It has long been known that infusions of herb mixtures, given to piglets as a preventive therapy, reduce the incidence of diarrhea and mortality, relieves gastrointestinal problems, stimulates appetite, feed intake and conversion, and increases the growth rate of piglets and weaners. ${ }^{13}$

A recent study showed that diet supplementation with oregano induces a higher glycoconjugate (GC) production in chicken broiler gut. In addition, other authors showed that the GCs produced by the goblet cells of the intestinal mucosal layer could be modified by the dietary variations, and also by vitamin and enzyme supplementation. ${ }^{14,15}$ In this context, studies have pointed to the importance of GCs in animal biology. GCs are carbohydrates of varying size and complexity, covalently linked to non-sugar moieties such as proteins, peptides, and lipids. Several studies have reported that these complex carbohydrates not only provide energy and structural materials but also participate in a plethora of biological processes. $^{16,17}$ The molecular and supramolecular scaffold of GCs enable them to perform a variety of functions, such as viral entry, signal transduction, inflammation, cell-cell interactions, bacteriahost interactions, fertility and development. ${ }^{18}$ Once secreted, the GCs cover the mucosa creating a continuous gel layer, which performs various functions: lubrication, barrier for certain low molecular weight solutes, proteolytic degradation and a physical/chemical barrier for microorganisms, parasites and their toxins. ${ }^{19,20}$ The biological relevance of complex carbohydrates is also indicated by their great variety in the same apparatus among different animal species, among different apparatuses of an animal species, and among different districts of the same apparatus. ${ }^{21-33}$ Many studies have explored the effect of oregano EO on different organ tissues, but to the best of our knowledge, few studies have focused on the effects of dietary administration of oregano aqueous extract (OAE) on animal diets, even though these products offer the advantages of containing the complete phyto-complexes rather than just the oily fraction, and of being solvent-free. , $14,34-38$ On the basis of the considerations described above, this research evaluated the effects of diet supplementation with OAE on complex carbohydrates in pig ileum and caecum, detected by glycohistochemistry, and on oxidative stress, detected by immunohistochemistry using as target molecule Bcl-2 Associate X protein (BAX). This study would also contribute to the exploration of the way to reduce antibiotic use and prevent antimicrobial resistance.

\section{Materials and Methods}

\section{Animals and experimental design}

Thirty-two Duroc x Large White pigs, randomly divided into 2 homogenous groups of 16 pigs each and housed in $3 \times 3 \mathrm{~m}$ pens containing 4 pigs each, were used.

The two experimental groups were fed according to one of the following finisher dietary treatments (from 120 to $180 \mathrm{~kg}$ live weight), which met the National Research Council (1998) nutrient requirements: 1) degermed corn-barley-soybean-based diet (CTR group); 2) CTR diet supplemented (2 $\mathrm{g} / \mathrm{kg}$ ) with OAE (O group). Animal growth performances were summarized in Table S1 showing a similar trend in the growth performance parameters in the two diet groups. The OAE was obtained by a process of bio-liquefaction based on enzyme bio-catalysis as previously reported. ${ }^{14,37}$ The OAE obtained was analysed to quantify antioxidant capacity (measured in terms of radical scavenging ability using the stable radical DPPH), total polyphenols (evaluated using the FolinCiocalteu reagent), and reducing sugars (evaluated using the ADNS method). In addition, an analysis of OEA samples was performed using GC-MS, to evaluate the percentage composition of volatile compounds (see Supplementary Material). The evaluation of the OAE antioxidant activity is reported in Table S2; the percentage composition of volatile compounds is reported in Table S3.

Water was provided ad libitum and the diets were wet (water to feed ratio of $3: 1$ ). The animals were slaughtered at 10 months of age at a public abattoir in accordance with the Art. 29 of the Council Regulation (EC) No. 1099/2009 on the protection of animals at the time of killing. The animal care procedures were in accordance with Legislative Decree No. 146, implementing Directive 98/58/EC of 20 July 1998 concerning the protection of animals kept for farming purposes. This research was approved with Protocol E81AC.10/A by the Ethics Committee of the University of Camerino, Italy.

\section{Morphological and histochemical analyses}

Specimens of ileum (removed just before the ileo-caecal fold insertion) and caecum (sampled in the middle) were collected from 8 animals of each group. Samples were immediately fixed by immersion in: a) Carnoy's fluid for $24 \mathrm{~h}$ followed by post-fixation in $2 \%$ calcium acetate $-4 \%$ paraformaldehyde solution (1:1) for $3 \mathrm{~h}$ at room temperature for conventional glycohistochemistry, ${ }^{38}$ b) $10 \%$ neutral-buffered formalin solution to evaluate the morphology and to perform the immunohistochemistry. All specimens were then dehydrated through a series of graded ethanol, cleared in xylene, embedded in paraffin wax and cut into 5 - $\mu$ m-thick serial sections. ${ }^{38}$ Sections were stained with haematoxylin and eosin (H\&E) for morphological analysis. ${ }^{39}$

Complex carbohydrate characterization was performed using the established screening staining procedures, carrying out the fol- 
lowing histochemical reactions: Periodic acid-Schiff (PAS), Alcian blue $(\mathrm{AB}) \mathrm{pH} 2.5, \mathrm{AB}-\mathrm{PAS}, \mathrm{AB} \mathrm{pH} 1, \mathrm{AB} \mathrm{pH} 0.5$, low iron diamine (LID), high iron diamine (HID). ${ }^{39}$ Adjacent serial sections were pre-treated with Sialidase (Sial, type V from Clostridium perfringens) before staining with $\mathrm{AB} \mathrm{pH} 2.5$ (Sial-AB). Before enzymatic treatment, some sections had been incubated with $1 \% \mathrm{KOH}$ in $70 \%$ ethanol for $20 \mathrm{~min}$ at room temperature to remove the acetyl groups (KOH-Sial-AB). ${ }^{23}$ Sugar moieties visualized by different histochemical treatments are shown in Table 1. The omission of enzymatic treatment on some sections was used as control for enzyme effectiveness.

For the study of oxidative stress, BAX protein was tested by immunohistochemical technique. ${ }^{40}$ Rehydrated sections were treated with $3 \% \mathrm{H}_{2} \mathrm{O}_{2}$ to reduce endogenous peroxidase activity and exposed to microwaves at 750 Watts in $0.1 \mathrm{M}$ citrate buffer $\mathrm{pH} 6.0$ to antigen retrieval. Successively, the sections were blocked with normal goat serum (Vector Laboratories, Burlingame, CA, USA) for $30 \mathrm{~min}$ and incubated overnight at room temperature with 1:100 mouse monoclonal anti-BAX antibody (Santa Cruz Biotechnology, Santa Cruz, CA, USA). The second day, sections were incubated for $30 \mathrm{~min}$ with 1:200 biotin-conjugated goat antimouse secondary antibody (Vector Laboratories). The immunohistochemical reaction was visualized by using an avidin-biotin system (Vectastain ABC kit; Vector Laboratories) and diaminobenzidine (DAB) as chromogen (Vector Laboratories). Sections in which the primary antibody was omitted, in addition to section treated with normal goat $\mathrm{IgG}$, were used as control of unspecific staining. All sections were observed under a photomicroscope (Nikon Eclipse E800, Nikon Corp., Tokyo, Japan).

For each animal, three independent observers evaluated five microscopic fields of each intestinal tract. The intensity of the staining was graded in arbitrary units as follows: negative $(-)$, weak $( \pm)$, moderate $(+)$, strong $(++)$ and very strong $(+++)$.

\section{Statistics}

With regard to the histochemical and immunohistochemical data, arbitrary units of reactivity, sorted in a scale ranging from 0 (negative) to 5 (very strong), were converted into ranks. We performed Wilcoxon rank sum tests: i) for each histochemical treatment and immunohistochemistry, under the null hypothesis that the location shift in the distributions of reactivity ranks of the two dietary groups is zero; ii) for each diet group, under the null hypothesis that the location shifts in the distributions of reactivity ranks between the serial treatments $\mathrm{AB} p H 2.5$ vs Sial-AB and Sial-AB vs KOH-Sial-AB is zero. The statistical significance threshold was set at $\mathrm{P}=0.05$. We performed statistical elaborations using the R ver. 3.0.2 (R Core Team, R Foundation for Statistical Computing, Vienna, 2013) and the stats R-package (wilcox.test function).

\section{Results}

Light microscope observation revealed no morphological differences between the two dietary groups evaluated; the morphological appearance was well preserved in both the ileum and the caecum. In the ileum, the villi were covered by enterocytes organized in a simple columnar epithelium, showing scattered goblet cells; in the villi basal area, epithelium extended into the lamina propria forming small intestinal crypts showing some goblet cells. In the caecum, epithelial lining strongly extended into the lamina propria forming deep intestinal crypts rich in goblet cells.

In relation to conventional glycohistochemical treatments, positivity was observed only at the goblet cell level. Differences emerged both between the two analysed intestinal regions and the two dietary groups. The $\mathrm{O}$ treatment generated in the ileum a differentiated reactivity to $\mathrm{HID}, \mathrm{AB} \mathrm{pH} 1$ and 0.5 of both villus and crypt goblet cells compared to that shown by the CTR samples. As regards the caecum, in both lower and upper crypt goblet cells, $\mathrm{O}$ samples showed a higher reactivity to $\mathrm{AB} \mathrm{pH} 2.5$ and LID than CTR samples. In addition, the response to $\mathrm{AB} \mathrm{pH} 2.5$, Sial-AB and $\mathrm{KOH}-\mathrm{Sial}-\mathrm{AB}$ sequential histochemical treatments induced differentiated reactivity of goblet cells in both ileum crypt goblet cells and caecum lower crypt goblet cells of O samples (Figure 1).

The reactivity of the samples to the various glycohistochemical treatments is summarized in Table 2, also showing the statistical analysis results. In Table 3, the significance of differences between the serial treatments $\mathrm{AB} \mathrm{pH}$ 2.5, Sial-AB and $\mathrm{KOH}-\mathrm{Sial}-\mathrm{AB}$ inside each diet group are shown.

On the basis of the histochemical findings, the kinds of glycoconjugates produced by goblet cells in pig ileum and caecum are listed in Tables 4 and 5, respectively, according to a descending semi-quantitative order. The specific glycoconjugate types were identified mostly on the basis of reactivity differences by comparing sequential treatments (i.e., $\mathrm{AB}$ at different $\mathrm{pH}$ values, LID vs HID, AB pH 2.5 vs Sial-AB vs KOH-Sial-AB, etc.). Results showed that, in the ileum the $\mathrm{O}$ diet promotes the production of chondroitin sulphate $\mathrm{A} / \mathrm{B} / \mathrm{C}$-like glycosaminoglycans in the crypt and villus goblet cells, and increases the production of sialilated glycoproteins not $\mathrm{C}_{4}$ acetylated in the crypt goblet cells (Table 4).

Table 1. Sugar moieties visualized by the histochemical treatments carried out.

Histochemical treatments Sugar moieties visualised

$\mathrm{AB} \mathrm{pH} 2.5$

Acidic groups: Sialic acid (SA), carboxylated (Hyaluronic acid, Chondroitin) and sulphated

(Chondroitin-sulphates A/B/C, Heparin, Heparansulphate) Glycosaminoglycan (GAG)-like material

\begin{tabular}{ll} 
Sial-AB & Acidic groups without C4 not acetilated SA \\
\hline KOH-Sial-AB & Asialilated acidic groups (GAG-like material) \\
$\mathrm{AB} \mathrm{pH1}$ & Sulphated GAG-like material (Chondroitin-sulphates A/B/C, Heparin, Heparansulphate) \\
\hline $\mathrm{AB} \mathrm{pH} 0.5$ & Highly sulphated GAG-like material (Heparin, Heparansulphate) \\
$\mathrm{PAS}$ & Vicinal hydroxyls (neutral and sialilated glycoproteins, GAG-like material) \\
\hline $\mathrm{AB} / \mathrm{PAS}$ & Acidic groups and vicinal hydroxyls \\
$\mathrm{LID}$ & Acidic groups \\
$\mathrm{HID}$ & Sulphated GAG-like material
\end{tabular}

GAG, glycosaminoglycan. 
In the caecum, the $\mathrm{O}$ diet promotes the production of sialilated glycoproteins not $\mathrm{C}_{4}$ acetylated in the lower crypt portion goblet cells (Table 5). The incubation of sections in enzyme-free buffer solution resulted in unmodified $\mathrm{AB}$ reaction (Figure $\mathrm{S} 1$ ).

In both the ileum and the caecum samples investigated, immunostaining revealed the presence of BAX protein. The pro- tein was produced by enterocytes that showed cytoplasmic immunostaining, while goblet cells were always negative. BAX staining was stronger at crypts than at lining level. As regards the differences between dietary groups, immunohistochemical analysis revealed weaker immunostaining of BAX in the ileum and caecum of O group compared with CTR group (Figure 2).
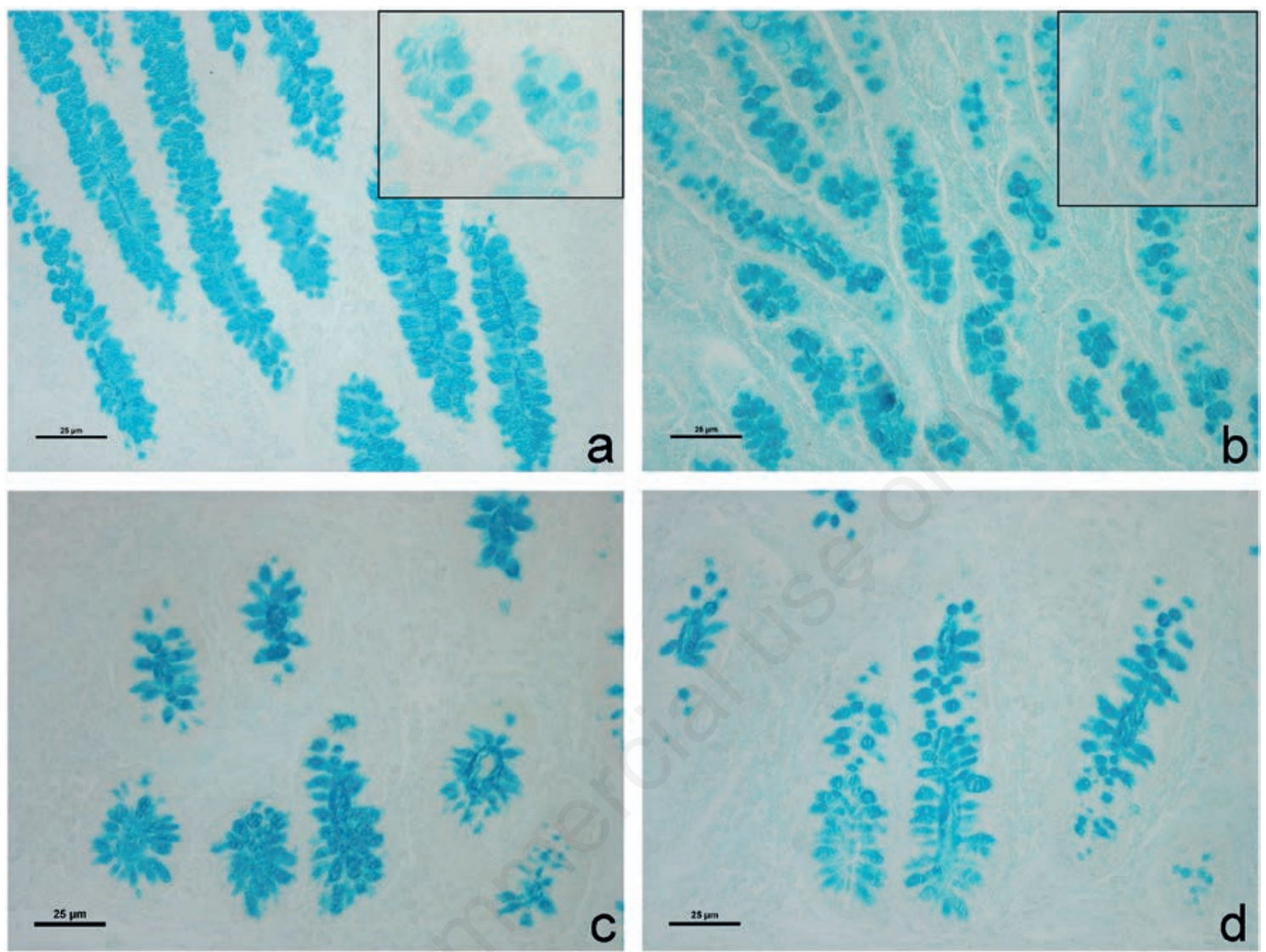

Figure 1. Swine ileum $(a, b)$ and caecum $(c, d)$ derived from the different experimental groups. Images show $A B$ strong reactivity of goblet cells pertaining to ileum intestinal crypts respectively in CTR (a) and O group (b). Sial-AB treatment produced differentiated effects in goblet cell reactivity less decreased in CTR (a, inset) than in the $\mathrm{O}$ group (b, inset). The $\mathrm{O}$ group caecum intestinal glands showed $\mathrm{AB}$ strong positivity (c) that was reduced by sialidase digestion (d) at lower crypt level.

Table 2. Histochemical response of pig ileum and caecum secretory structures.

\begin{tabular}{|c|c|c|c|c|c|c|c|c|c|c|c|c|}
\hline \multirow{3}{*}{$\begin{array}{l}\text { Histochemic } \\
\text { treatments }\end{array}$} & \multirow{2}{*}{\multicolumn{4}{|c|}{$\begin{array}{c}\text { Ileum } \\
0\end{array}$}} & \multirow{2}{*}{\multicolumn{2}{|c|}{$\mathbf{P}$}} & \multicolumn{6}{|c|}{ Caecum } \\
\hline & & & & & & & & & & 0 & I & $p$ \\
\hline & $\begin{array}{l}\text { Crypt } \\
\text { GC }\end{array}$ & $\begin{array}{l}\text { Villus } \\
\text { GC }\end{array}$ & $\begin{array}{l}\text { Crypt } \\
\text { GC }\end{array}$ & $\begin{array}{l}\text { Villus } \\
\text { GC }\end{array}$ & $\begin{array}{l}\text { Crypt } \\
\text { GC }\end{array}$ & $\begin{array}{l}\text { Villus } \\
\text { GC }\end{array}$ & $\begin{array}{l}\text { Upper } \\
\text { crypt } \\
\text { GC }\end{array}$ & $\begin{array}{l}\text { Lower } \\
\text { crypt } \\
\text { GC }\end{array}$ & $\begin{array}{l}\text { Upper } \\
\text { crypt } \\
\text { GC }\end{array}$ & $\begin{array}{c}\text { Lower } \\
\text { crypt } \\
\text { GC }\end{array}$ & $\begin{array}{l}\text { Upper } \\
\text { crypt } \\
\text { GC }\end{array}$ & $\begin{array}{l}\text { Lower } \\
\text { crypt } \\
\text { GC }\end{array}$ \\
\hline $\mathrm{AB}$ pH 2.5 & ++ & ++ & ++ & $\pm /++$ & 1 & 0.0122 & $+/++$ & $+/++$ & ++ & ++ & 0.0112 & 0.0112 \\
\hline Sial-AB & + & ++ & $\pm /+$ & $\pm /++$ & 0.0102 & 0.0122 & $+/++$ & $+/++$ & ++ & $+/++$ & 0.0112 & 1 \\
\hline KOH-Sial-AB & + & ++ & $\pm /+$ & $\pm /++$ & 0.0278 & 0.0112 & $+/++$ & $+/++$ & ++ & $+/++$ & 0.0117 & 0.8212 \\
\hline $\mathrm{AB} \mathrm{pHl}$ & + & + & $\pm /+$ & $\pm /++$ & 0.0181 & 0.0465 & $\pm /+$ & $\pm /+$ & $\pm /+$ & $\pm /+$ & 1 & 1 \\
\hline $\mathrm{AB} \mathrm{pH} 0.5$ & + & + & $-1 \pm$ & $-1+$ & 0.0117 & 0.0112 & $\pm /+$ & $\pm /+$ & $\pm /+$ & $\pm /+$ & 1 & 1 \\
\hline PAS & ++ & $+/++$ & ++ & $+/++$ & 1 & 1 & $+/++$ & + & + & + & 0.0107 & 1 \\
\hline $\mathrm{AB} / \mathrm{PAS}$ & $\mathrm{B}++/ \mathrm{R}-/+$ & $\mathrm{B}++/ \mathrm{R}-/+$ & $\mathrm{B}++/ \mathrm{R}-/++$ & $\mathrm{B} \pm /++/ \mathrm{R}++$ & 0.0109 & 0.0112 & $\mathrm{~B}++/ \mathrm{R}-$ & $\mathrm{B}++/ \mathrm{R}-$ & $\mathrm{B}++/ \mathrm{R}-/+$ & $\mathrm{B}++/ \mathrm{R}-/+$ & 0.0117 & 0.0112 \\
\hline LID & ++ & ++ & ++ & $\pm /++$ & 1 & 0.0117 & $+/++$ & $+/++$ & ++ & ++ & 0.0117 & 0.0107 \\
\hline HID & + & + & $\pm /+$ & $\pm /++$ & 0.0562 & 0.0147 & $\pm /+$ & $\pm /+$ & $\pm /+$ & $\pm /+$ & 0.8212 & 1 \\
\hline
\end{tabular}

Intensity of staining in tissue sections was scored as follows: negative $(-)$, weak $( \pm)$, moderate $(+)$, strong $(++)$; slashes indicate that the staining intensity score is between the two indicated scores GC, goblet cells; B, Blue stain; R, Red stain; P, statistical significance of differences for each histochemical treatment between CTR and 0 diets: $P=0.05$. 
In particular, mainly difference was observed in pig caecum as summarized in Table 6, which also shows the significance of differences between the two dietary treatments. No staining was observed in the negative controls (Figure S2).

\section{Discussion}

In the last years, an increasing research activity on different substances able to improve health and/or welfare status of pigs, especially concerning the effects of nutraceutical ingredients (feed additives) such as plant extracts was observed. Origanum vulgare possesses multiple pharmacological characteristics and its antioxidant and antibacterial properties are particularly interesting. This study investigated the effects of oregano feed supplementation on antioxidant and defence ability of pig gut, by means of glyco- and immunohistochemistry.

Analysis of the histochemical results revealed that goblet cells of animals fed with the two dietary treatments expressed different types of glycoconjugates, as shown in Tables 5 and 6. The increased goblet cells reactivity to $\mathrm{HID}, \mathrm{AB} \mathrm{pH} 1$ and 0.5 at ileum level, and to $\mathrm{AB}$ pH 2.5 and LID at caecum one, observed in $\mathrm{O}$ samples respect to CTR samples, demonstrated that the $\mathrm{O}$ group showed higher production of acidic GCs.

In particular, the $\mathrm{O}$ diet induced ileum goblet cells to produce chondroitin sulphate $\mathrm{A} / \mathrm{B} / \mathrm{C}$-like glycosaminoglycans, which are able to draw large amounts of water promoting a better tissue hydration; in addition, they could act as hapten-like binding sites, enveloping pathogenic bacteria, viruses and parasites preventing them from damaging the intestinal mucosae..$^{41,42}$ This effect could also support the microbiota action especially in relation to Lactobacillus spp.; indeed, preliminary data showed that Lactobacillus spp. increased in O diet with respect to the CTR one (data not shown). It is also consistent with the results observed in poultry species following diet supplemented with oregano essential oils. ${ }^{11,37,43-46}$ Lactobacillus spp. are beneficial bacteria able to counteract pathogen organisms in colonizing intestinal epithelium. ${ }^{47}$ Furthermore, $\mathrm{O}$ diet supplementation seems to enhance the negative charge amount of the viscoelastic barrier secreted by the swine gut goblet cells; this may represent a steric hindrance able to repulse pathogens. ${ }^{48}$ Finally, differentiated reactivity of goblet cells to AB $\mathrm{pH} 2.5$, Sial-AB and KOH-Sial-AB sequential treatments evidenced that the $\mathrm{O}$ supplementation increased the sialoglycoprotein production in the pig ileum and promoted the secretion of sialoglycoproteins in the pig caecum, providing also a certain degree of defense. ${ }^{23,28,49}$ Origanum vulgare L. has been shown to possess several properties including the antioxidant one that is of special interest. $^{2}$ Therefore, the expression of BAX was investigated in the ileum and caecum of swine according to the different diet supplementation. ROS and free radicals are produced in the cells following the oxidative reactions and their accumulation can lead to pathological condition. In response to severe or protract stress signals, the cell can show irreversible apoptosis or senescence programs. Apoptosis is regulated by the members of $\mathrm{Bcl}-2$ family such as the BAX protein. ${ }^{49}$

Table 3. Statistical significance of differences between histochemical sequential treatments to remove sialic acid $(P<0.05)$.

\begin{tabular}{|c|c|c|c|c|}
\hline Intestinal tract & Diet & Secretory structure & $\mathrm{AB}$ pH 2.5 us Sial-AB & Sial AB vs KOH-Sial-AB \\
\hline Ileum & $\begin{array}{c}\text { CTR } \\
0\end{array}$ & $\begin{array}{l}\text { Crypt GC } \\
\text { Villus GC } \\
\text { Crypt GC } \\
\text { Villus GC }\end{array}$ & $\begin{array}{c}0.01066 \\
1 \\
0.01116 \\
1\end{array}$ & $\begin{array}{l}1 \\
1 \\
1 \\
1\end{array}$ \\
\hline Caecum & $\begin{array}{c}\text { CTR } \\
0\end{array}$ & $\begin{array}{l}\text { Upper crypt GC } \\
\text { Lower crypt GC } \\
\text { Upper crypt GC } \\
\text { Lower crypt GC }\end{array}$ & $\begin{array}{c}1 \\
1 \\
1 \\
0.01116\end{array}$ & $\begin{array}{l}1 \\
1 \\
1 \\
1\end{array}$ \\
\hline
\end{tabular}

GC, goblet cells.

Table 4. Glycoconjugates expressed by pig ileum under the two different dietary treatments.

\begin{tabular}{lll} 
& Complex carbohydrates expressed by crypt GC & Complex carbohydrates expressed by villus GC \\
CTR & Heparin/Heparansulphate-like GAGs & Hyaluronic acid/Chondroitin-like GAGs \\
& Sialilated glycoproteins not $\mathrm{C}_{4}$ acetylated & Heparin/Heparansulphate-like GAGs \\
Sialilated glycoproteins not $\mathrm{C}_{4}$ acetylated & Chondroitinsulphate A/B/C-like GAGs \\
Chondroitinsulphate $\mathrm{A} / \mathrm{B} / \mathrm{C}$-like GAGs & Heparin/Heparansulphate-like GAGs \\
& Heparin/Heparansulphate-like GAGs & \\
\hline
\end{tabular}

GC, goblet cells; GAGs, glycosaminoglycans.

Table 5. Glycoconjugates expressed by pig caecum under the two different dietary treatments. Complex carbohydrates expressed by upper crypt portion GC Complex carbohydrates expressed by lower crypt portion GC

CTR Hyaluronic acid/Chondroitin-like GAGs Heparin/Heparansulphate-like GAGs

O Hyaluronic acid/Chondroitin-like GAGs Heparin/Heparansulphate-like GAGs
Hyaluronic acid/Chondroitin-like GAGs Heparin/Heparansulphate-like GAGs

Hyaluronic acid/Chondroitin-like GAGs Heparin/Heparansulphate-like GAGs Sialilated not $\mathrm{C}_{4}$ acetylated glycoproteins

GC, goblet cells; GAGs, glycosaminoglycans. 
In our study, the BAX protein was observed in the enterocytes of both the ileum and caecum samples, but there was weaker immunostaining in the $\mathrm{O}$ group samples than in the CTR group. This lower expression of BAX protein in the $\mathrm{O}$ group samples, especially in the caecum, suggests that the OAE supplementation has a positive antioxidative effect on tissues. In conclusion, our results show that there was improved production of GCs in the ileum and caecum of pigs fed a diet supplemented with oregano aqueous extract, and thus enhanced protection of the mucosa of these sections of the intestine. In addition, we observed enhanced antioxidant action in the ileum and caecum samples of the oregano supplemented group, as revealed in less BAX immunostaining in O group samples compared to CTR group samples. Although the CTR diet shows a good picture regarding both the GCs and the BAX expression, the addition of OAE to the diet strongly enhances the defence and antioxidant abilities in pig ileum and especially in pig caecum.

Our findings, in agreement with those reported for pig duodenum and colon $^{38}$ demonstrate that histochemical investigation can be useful to obtain additional information on the OAE positive effects on pig gut. Comparing the findings emerged by this study with those obtained in pig duodenum and colon, we can affirm that the segments of small intestine are the most sensitive to the OAE effects. ${ }^{38}$ In fact, they showed the most evident differences between experimental and control group regarding both the complex GCs and the BAX reactivity. The results of this study can be used in further research to identify ways to enhance endogenous defence ability, with the aim of reducing antibiotic use and preventing antimicrobial resistance. This could be particularly interesting for the organic production.

Table 6. Intensity of immunostaining in tissue sections was scored as follows: moderate $(+)$, strong $(++)$, very strong $(+++)$.

\begin{tabular}{lccc} 
& CIR & 0 & P \\
Ileum & ++ & + & 0.000 \\
Caecum & +++ & + & 0.000 \\
\hline
\end{tabular}

P, statistical significance of differences between CTR and 0 diets.
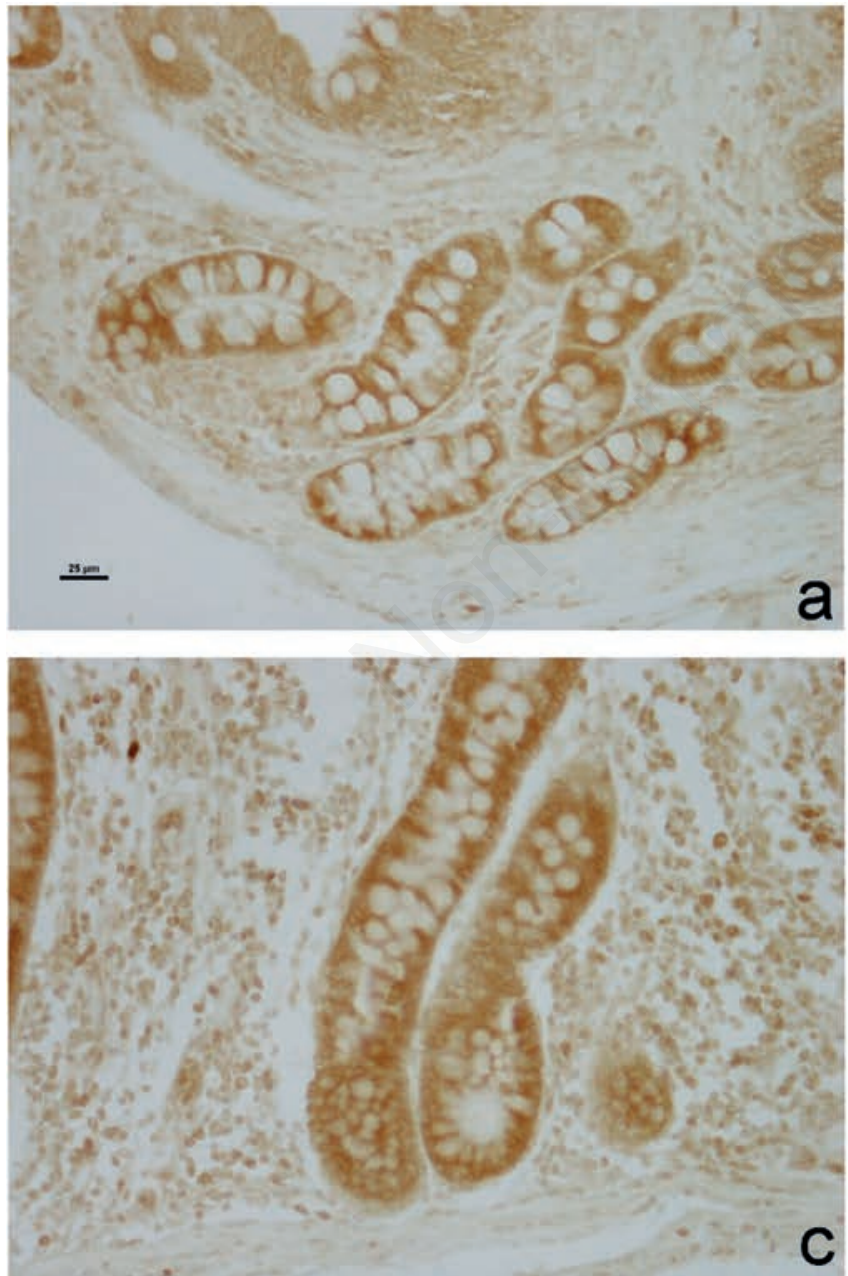
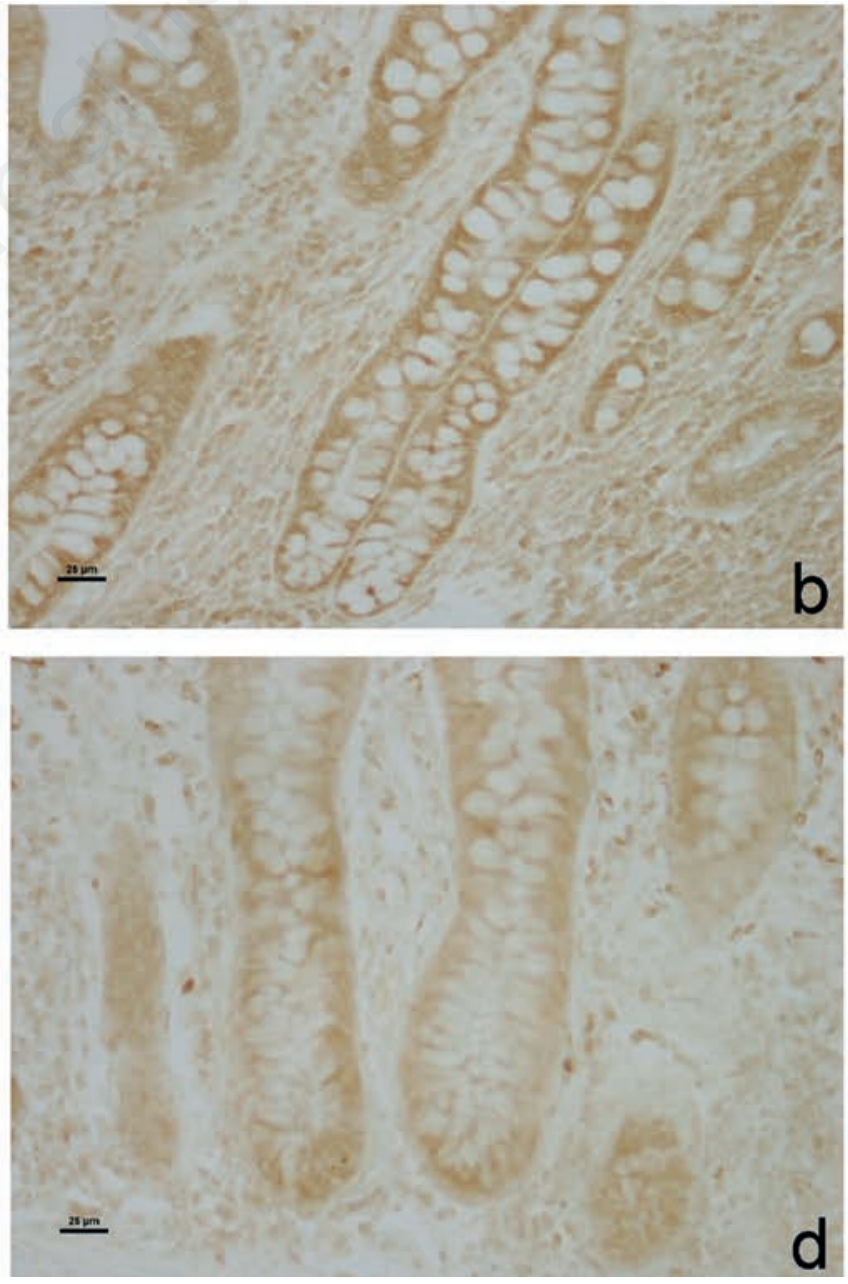

Figure 2. BAX immunohistochemistry in swine gut. DAB staining is showed in the lamina propria intestinal glands of the ileum (a,b) and caecum $(c, d)$. Immunostaining is stronger in the CTR group $(a, c)$ than the $O$ group $(b, d)$. 


\section{Acknowledgments}

The authors are grateful to Dr. Paola Coliolo and Mrs. Maria Gabriella Mancini for their excellent technical support. The authors would also like to thank Sheila Beatty for editing the English usage in the manuscript.

\section{References}

1. Moradi M, Hassani A, Ehsani A, Hashemi M, Raeisi M, Naghibi SS. Phytochemical and antibacterial properties of Origanum vulgare ssp. gracile growing wild in Kurdistan Province of Iran. J Food Qual Hazards Control 2014;1:120-4.

2. De Falco E, Mancini E, Roscigno G, Mignola E, TaglialatelaScafati O, Senatore F. Chemical composition and biological activity of essential oils of Origanum vulgare L. subsp. Vulgare L. under different growth conditions. Molecules 2013;18:14948-60.

3. Ashraf Z, Muhammad A, Imran M, Tareq AH. In vitro antibacterial and antifungal activity of methanol, chloroform and aqueous extracts of Origanum vulgare and their comparative analysis. Int J Org Chem 2011;1:257-61.

4. Halliwell B. Biochemistry of oxidative stress. Biochem Soc Trans 2007;35:1147-50.

5. Frijhoff J, Winyard PG, Zarkovic N, Davies SS, Stocker R, Cheng D, et al. Clinical relevance of biomarkers of oxidative stress. Antiodix Redox Signal 2015;23:1144-70.

6. Lushchak VI. Free radicals, reactive oxygen species, oxidative stress and its classification. Chem Biol Interact 2014;224:164-75.

7. García-Beltrán JM, Ángeles Esteban M. Properties and applications of plants of Origanum Sp. genus. SM J Biol 2016; 2:1006.

8. Betancourt L, Phandanauvong V, Patiño R, Ariza-Nieto C, Afanador-Téllez G. Composition and bactericidal activity against beneficial and pathogenic bacteria of oregano essential oils from four chemotypes of origanum and lippia genus. Rev Med Vet Zoot 2012;59:21-31.

9. Jamroz D, Wertelecki T, Houszka M, Kamel C. Influence of diet type on the inclusion of plant origin active substances on morphological and histochemical characteristics of the stomach and jejunum walls in chicken. J Anim Physiol Anim Nutr 2006;90:255-68.

10. Windisch WM, Schedle K, Plitzner C, Kroismayr A. Use of phytogenic products as feed additives for swine and poultry. J Anim Sci 2008;86:E140-8.

11. Zeng Z, Zhang S, Wang H, Piao X. Essential oil and aromatic plants as feed additives in non-ruminant nutrition: a review. J Anim Sci Biotechnol 2015;6:1-10.

12. Lambert RJW, Skandamis PN, Coote P, Nychas GJE. A study of the minimum inhibitory concentration and mode of action of oregano essential oil, thymol and carvacrol. J Appl Microbiol 2001;91:453-62.

13. Rekiel A, Wiecek J. Effect of preparations Biogen and Microferm-fer on the rearing results of piglets. Veterin Med 1996;52:187-9.

14. Scocco P, Forte C, Franciosini MP, Mercati F, CasagrandeProietti P, Dall'Aglio C, et al. Gut complex carbohydrates and intestinal microflora in broiler chickens fed with oregano (Origanum vulgare L.) aqueous extract and vitamin E. J Anim Physiol Anim Nutr 2017;101:676-84.

15. Sharma R, Fernandez F, Hinton G, Schumacher U. The influence of diet on the mucin carbohydrates in the chick intestinal tract. Cell Mol Life Sci 1997;53:935-42.
16. Wiederschain GY. Glycobiology: progress, problems, and perspectives. Biochemistry 2013;78:679-96.

17. Varki A. Biological roles of glycans. Glycobiology 2017;27:3-49.

18. Crucho CI, Correia-da-Silva P, Petrova KT, Barros MT. Recent progress in the field of glycoconjugates. Carbohydr Res 2015;402:124-32.

19. Bosi G, Arrighi S, Di Giancamillo A, Domeneghini C. Histochemistry of glycoconjugates in mucous cells of Salmo trutta uninfected and naturally parasitized with intestinal helminthes. Dis Aquat Organ 2005;64:45-51.

20. Scocco P, Pedini V. Equine mandibular gland: in situ characterisation of sialoderivatives. Equine Vet J 2006;38:410-5.

21. Domeneghini C, Arrighi S, Radaelli G, Bosi G, Veggetti A. Histochemical analysis of glycoconjugate secretion in the alimentary canal of Anguilla anguilla L. Acta Histochem 2005; 106:477-87.

22. Gebert, al-Samir K, Werner K, Fassbender S, Gebhard A. The apical membrane of intestinal brush cells possesses a specialised, but species-specific, composition of glycoconjugates-on-section and in vivo lectin labelling in rats, guinea-pigs and mice. Histochem Cell Biol 2000;113:389-99.

23. Scocco P, Pedini V. Histochemical characterisation of complex carbohydrates expressed in the alimentary tract of chickens. Vet J 2010;185:228-30.

24. Schulte BA, Spicer SS. Light microscopic detection of sugar residues in glycoconjugates of salivary glands and the pancreas with lectin-horseradish peroxidase conjugates. I. Mouse. Histochem J 1983;15:1217-38.

25. Burkett BN, Schulte BA, Spicer SS. Histochemical evaluation of glycoconjugates in the male reproductive tract with lectinhorseradish peroxidase conjugates: II. Staining of ciliated cells, basal cells, flask cells, and clear cells in the mouse. Am J Anat 1987;178:23-9.

26. Menghi G, Bondi AM, Materazzi G. Distribution of lectin binding sites in rabbit oviduct. Anat Rec 1985;211:279-84.

27. Menghi G, Bondi AM, Accili D, Materazzi G. Visualization of carbohydrate chains in rabbit salivary glands by means of enzymatic degradation and plant lectins. Acta Histochem 1988;84:163-77.

28. Scocco P, Pedini V. Localization of influenza virus sialoreceptors in equine respiratory tract. Histol Histopathol 2008; 23:973-8.

29. Scocco P, Menghi G, Ceccarelli P. Glycohistochemistry of the Tilapia spp. stomach. J Fish Biol 1996;49:584-93.

30. Scocco P, Menghi G, Ceccarelli P. Histochemical differentiation of glycoconjugates occurring in the tilapine intestine. J Fish Biol 1997;51:848-57.

31. Scocco P, Accili D, Menghi G, Ceccarelli P. Unusual glycoconjugates in the oesophagus of a tilapine polyhybrid. J Fish Biol 1998;53:39-48.

32. Pedini V, Dall'Aglio C, Parillo F, Scocco P. A lectin histochemical study of the oesophagus of shi drum. J Fish Biol 2004; 64:625-31.

33. Pedini V, Dall'Aglio C, Parillo F, Scocco P. Glycoconjugate distribution in gastric fundic mucosa of Umbrina cirrosa $\mathrm{L}$. revealed by lectin histochemistry. J Fish Biol 2005;66:222-9.

34. Papageorgiou G, Botsoglou NA, Govaris A, Giannenas I, Iliadis S, Botsoglou E. Effect of dietary oregano oil and alphatocopheryl acetate supplementation non iron-induced lipid oxidation of turkey breast, thigh, liver and heart tissues. J Anim Physiol Anim Nutr 2003;87:324-35.

35. Zou Y, Xiang Q, Wang J, Peng J, Wei H. Oregano essential oil improves intestinal morphology and expression of tight junction proteins associated with modulation of selected intestinal bacteria and immune status in a pig model. Biomed Res Int 
2016;5436738.

36. Liu Q, Duan RJ, Zhou YF, Wei HK, Peng J, Li JL. Supplementing oregano essential oil to boar diet with strengthened fish oil: effects on semen antioxidant status and semen quality parameters. Andrologia 2017;49:e12764.

37. Franciosini MP, Casagrande-Proietti P, Forte C, Beghelli D, Acuti G, Zanichelli D, et al. Effects of oregano (Origanum vulgare L.) and rosemary (Rosmarinus officinalis L.) aqueous extracts on broiler performance, immune function and intestinal microbial population. J Appl Anim Res 2016;44:474-9.

38. Mercati F, Dall'Aglio C, Acuti G, Faeti V, Tardella FM, Pirino $\mathrm{C}$, et al. Oregano feed supplementation affects glycoconjugates production in swine gut. Animals 2020;10:149.

39. Pearse AGE. Histochemistry. Theoretical and Applied. Churchill Livingstone; Edinburgh; 1985.

40. Dall'Aglio C, Polisca A, Cappai MG, Mercati F, Troisi A, Pirino $\mathrm{C}$, et al. Immunohistochemistry detected and localized cannabinoid receptor type 2 in bovine fetal pancreas at late gestation. Eur J Histochem 2017;61:2761.

41. Scocco P, Fagioli O, Ceccarelli P, Pedini V. From conventional to modern histochemistry: a way for the fine characterization of secretion glycoconjugates. It J Anat Embryol 2002;3:43-54.

42. Frick IM, Schmidtchen A, Sjobring U. Interactions between M proteins of Streptococcus pyogenes and glycosaminoglycans promote bacterial adhesion to host cells. Eur J Biochem 2003; 270:2303-11.
43. Castillo M, Martín-Orúe SM, Manzanilla EG, Badiola I, Martín M Gasa J. Quantification of total bacteria, enterobacteria and lactobacilli populations in pig digesta by real-time PCR. Vet Microbiol 2006;1142:165-70.

44. Wei HK, Xue HX, Zhou Z, Peng J. A carvacrol-thymol blend decreased intestinal oxidative stress and influenced selected microbes without changing the messenger RNA levels of tight junction proteins in jejunal mucosa of weaning piglet. Animal 2017;11:193-201.

45. Cetin N, Güçlü BK, Cetin E. The effects of probiotic and mannanoligosaccharide on some haematological and immunological parameters in Turkeys. J Vet Med A Physiol Pathol Clin Med 2005;52:263-7.

46. Mead GC. Prospects for competitive exclusion treatment to control Salmonella and other food borne pathogens in poultry. Vet J 2000;159:111-23.

47. Liu H, Hou C, Wang G, Jia H, Yu H, Zeng X, et al. Lactobacillus reuteri $\mathrm{I} 5007$ modulates intestinal host defense peptide expression in the model of IPEC-J2 cells and neonatal piglets. Nutrients 2017;9:559.

48. Werling D. The clinical significance of sialoderivatives in the search for novel means of antipathogen teraphy. Equine Vet $\mathrm{J}$ 2006;38:390-2.

49. Nieuw-Amerongen AV, Bolscher JGM, Veerman ECI. Salivary mucins: protective functions in relation to their diversity. Glycobiology 1995;5:733-40.

Received for publication: 15 January 2020. Accepted for publication: 10 February 2020.

This work is licensed under a Creative Commons Attribution-NonCommercial 4.0 International License (CC BY-NC 4.0).

CCopyright: the Author(s), 2020

Licensee PAGEPress, Italy

European Journal of Histochemistry 2020; 64:3110

doi:10.4081/ejh.2020.3110 